CATALAN REVIEW

Catalan Review



You are accessing the Digital Archive of the Catalan Review Journal.

By accessing and/or using this Digital Archive, you accept and agree to abide by the Terms and Conditions of Use available at http://www.nacs-

catalanstudies.org/catalan review.html

Catalan Review is the premier international scholarly journal devoted to all aspects of Catalan culture. By Catalan culture is understood all manifestations of intellectual and artistic life produced in the Catalan language or in the geographical areas where Catalan is spoken. Catalan Review has been in publication since 1986.
NORTH

AMERICAN

CATALAN

SOCIETY
Esteu accedint a l'Arxiu Digital del Catalan Review

A l' accedir i / o utilitzar aquest Arxiu Digital, vostè accepta i es compromet a complir els termes i condicions d'ús disponibles a http://www.nacs-

catalanstudies.org/catalan review.html

Catalan Review és la primera revista internacional dedicada a tots els aspectes de la cultura catalana. Per la cultura catalana s'entén totes les manifestacions de la vida intel lectual i artística produïda en llengua catalana o en les zones geogràfiques on es parla català. Catalan Review es publica des de 1986.

\title{
The Angel at the Desk: Reading, Work, and Domesticity in La fabricanta Kathleen Davis
}

Catalan Review, Vol. XV, No. 2 (2001), p. 49-59 


\title{
THE ANGEL AT THE DESK: \\ READING, WORK, AND DOMESTICITY \\ IN LA FABRICANTA
}

KATHLEEN DAVIS

\begin{abstract}
$\mathrm{O}$ ne of the most esteemed and decorated Catalan authors of the decades spanning the turn of the century, Dolors Monserdà de Macià was also one of the most active female journalists of her time. Monserdà served as director or collaborator on such periodicals as $L a$ Llar, Modas y Labors, El Figurrn Artístico, La Ilustración de la Mujer, Or y Grana, Feminal, and Acción Católica Femenina. An ardent nationalist and an active participant in the Renaixença, the literary movement which promoted the Catalan language, Monserdà devoted much of her energy to works specifically aimed at a female readership, writing with the conviction of women's importance to the education of citizens and the formation of a nationalist consciousness.
\end{abstract}

Deixeu que la dona, al educar els seus fills en l'amor de Deu y de la familia, hi ajunti'l de la patria, y no temau pel pervindre de Catalunya: aquells fills, que en aquestos tres amors nodrirán en el fons del seu esperit el noble sentiment del dever, el dia de las eleccións votarán homes que, com ells l'han complert en las urnas, el sápigan complir en el Parlament. ("Carta oberta" 3-4)

The domestic sphere has tremendous importance for Monserdà as the site of transmission of Catalan history and culture; she sees national values as ultimately being in the hands of women in their dual roles as mothers/teachers. As a writer, Monserdà hopes to foster a sense of cultural solidarity among adult women by addressing their common interests in the Catalan language. In the inaugural issue of the magazine Modas $y$ Labors, lamenting that few periodicals written in Catalan reach a female readership, Monserdà writes:

La moda, eixa regina tan déspota, tan voluble, pero qual jóu acatem ab tan gran sumissió, quals decrets per obehirlos cerquém ab tan ardent interés, será la missatjera, qu'en alas del desitj de propagar la llengua pátria, s'obri pas per son interés y utilitat entre las damas catalanas, oferintlas una publicació, que no escasseijant quants esforsos sian precisos pera portar notablement a cap la empresa, 'Is hi doni compte en la parla de la terra, y en reproduccions d'artistichs y elegants figurins, de las últimas novetats que relativas a modas y labors

1. The quotations from periodicals do not observe standardized spelling of Catalan. I have copied them exactly as they appear. 
tinguen lloch no sols en la capital de la vehina Fransa, sino en altres punts ahont se produheixin y que millor s'adaptin al gust y modo de ser de nostra hermosa cuitat. ("A nostras lectoras" I)

Monserdà's career as a some-time fashion writer may seem at odds with the conservative, anti-consumerist themes of some of her novels. The author is ambivalent towards fashion, but she is willing to urilize the seemingly frivolous medium of the fashion magazine as a vehicle for a nationalist project-in this case, the promotion of Catalan. Monserdà's novels also show a curious, reflexive ambivalence. Antònia Tayadella i Oller points out that Monserdà disapproved of novels because she believed that they fostered an attitude of fantasy and "bovarism." At the same time, she was eager to take advantage of the genre as the most effective manner of conveying her moral ideology to a large audience (Tayadella i Oller 540). Monserdà had serious moral reservations about the novel, but she also has an awareness of the power of the acts of reading and writing to shape consciousness in a manner that ultimately has political implications.

Dolors Monserdà wrote La fabricanta in 1904 , bestowing on the work the subtitle Novel.la de costums barcelonines (1860-1875). In her prologue, Monserdà rather disingenuously warns the reader who may be seeking the passions represented in other books that here she will find only "un enfilall de casolanes intimitats" (37). The action of the novel is set some forty years in the past in order to preserve a record of "tipus i fets que la moderna constitució de la indústria i el modo d'ésser de la societat actual fan quasi impossible que tornen a existir" (38). In La fabricanta, Monserdà reconstitutes a nostalgic representation of Barcelona's burgeoning textile industry through the tale of two households, two pictures of domesticity. Yet, in several respects, the novel is about reading. On one level, the domestic drama itself treats the lives of two women whose reading material leads them into opposing lifestyles and opposing systems of domestic economy. In addition, Monserdà uses the novel to provide her own readers with an artistic reordering of the textile industry according to domestic and family models.

In his discussion of the history of the consumer ethic, Colin Campbell notes the nearly simultaneous emergence of modern consumerism, the sentimental novel, and the idea of romantic love $(26-27)$. The enjoyment of all three, Campbell asserts, is predicated on the subject's indulgence in illusory hedonism, a "generalized longing for the fulfillment of dreams" (176). Florentina, the younger, more attractive of two cousins who are the principal characters of $\mathrm{La}$ fabricanta, is an enthusiast of sentimental novels, preferably French ones. Her consumption of one novel after another fuels her 
consumption of luxury goods, as she attempts to make her surroundings resemble, as far as possible, imagined literary scenes. Any object that recalls the "everydayness" of life must be carefully filtered out of the environment because, as Florentina flatly states, "Les coses lletges, no hi puc fer més, me sembla que em crispen los nervis" (I48). Florentina is not from a poor family, and a taste for luxury goods fed by romance novels would not be so bad, if things ended there. Unfortunately, Florentina's expectations about people and emotions have been unrealistically heightened by her reading material. Her dissatisfaction with the world around her, her need to imagine herself in new scenes and situations extends to the desire to repopulate her life with the persons she "meets" in novels.

Florentina is of marriageable age and has a firm idea of what she wants in a husband:

...lo meu únic ideal per a casar-me és tenir un marit que estigui ben bojament enamorat de mi...Miri: ara llegeixo una història en què hi ha un tal Armando que, si vostè sapigués tot lo que fa per una senyora que li diuen la dama de las camelias, veuria lo que ha d'afalagar veure's estimada amb tanta passió. (I57)

Florentina insists that she will accept as a husband only someone in such extremes of passion that he would give up fortune, reputation and family if called on to do so, a man "que sia com explica $L a$ indiana" (62). Whenever she speaks, Florentina expresses herself in terms of novels. If her views are challenged, she points out that, having read so many books, she has wider knowledge. For Florentina, books supplant experience itself. She does not simply refurnish the world around her so that it resembles the books she reads; the world of novels is more real to her than the world in which her everyday life transpires. The concrete elements of daily life are only props to be rearranged so as to most closely reproduce the romantic visions of life in novels. Florentina experiences the world through her imagination to such a degree that, if she is short of novels, she reads in circlesstarting again at the beginning of the book she has just finished.

In spite of her stringent requirements for a husband, Florentina does not choose from among many suitors; she takes the man who first presents himself, Josep Corominas. Corominas is a dry man of few words, but Florentina rewrites his proposal of marriage in accordance with the romantic style she prefers:

...1a Florentina, que amb sa exaltada imaginació, comparà tot seguit la veritat i potència d'aquell amor que per tants anys havia subsistit callat i sens esperança d'ésser correspost, amb lo dels molts hèroes de novel-la que havia llegit; i, engrandint i poetisant l'enamorament del seu cosí, a l'arribar a sa casa li faltà temps per a contar-ho a la seva mare amb tots los perfils i relleus que li suggerí el goig d'haver inspirat tan romàntica passió. (124) 
Josep functions only as a kind of tabula rasa on which Florentina can project the desired male qualities as gleaned from novels. Her preconceived notions of how men should be prevent her from actually knowing any men at all. For this reason, Florentina does not even notice that she has abdicated the privilege of making a selection based on a knowledge of the qualities of several possible candidates. Pep's actual characteristics hardly matter, except in the event that he might present an obstacle to Florentina's desires, clashing with her expectations of how an Armand Duval would behave towards Camille. In agreeing to become Josep's wife, Florentina is consuming an image of a romantic hero without considering the real man in question.

Antonieta Corominas, Florentina's cousin and future sister-inlaw, has all the characteristics of the domestic angel which had become common in didactic fiction by the time Monserdà composed La fabricanta: piety, modesty and frugality. Twenty-seven years of age, Antonieta has been content to stay at home and keep house for her brother, until news of his proposed marriage to Florentina provides his sister with an incentive to seek a husband of her own. As a preface to Antonieta's pursuit of a husband, Monserdà describes in detail Antonieta's education. The young woman is disposed to be a hard worker, and, while at school, she excelled in arithmetic, the subject that will be most useful to her in domestic management. In contrast to Florentina, Antonieta's reading material is of the most exemplary nature: El Año Cristiano, La Revista Popular, and Las Madres Católicas. (The first women's periodicals in Catalan had yet to appear.)

Antonieta's expectations of a man are simple; she asks only for "un home de bé i treballador" (98). However, Antonieta selects Pere Joan Grau knowing even less about him than Florentina does about Josep. Antonieta has seen Pere Joan pass by her house several times; she finds him attractive and learns that he has regular work as a weaver. Upon seeing Pere Joan at church, Antonieta decides that God has given her a sign that the two belong together. In the convent school, Antonieta was never exposed to frivolous books, but Christian and wholesome as her reading may have been, her expectations and her interpretations of events are still shaped by what she has read. In spite of Monserda's assertion that Antonieta is all the better for not having had "estudis amb què les modernes corrents s'empenyen en marejar la intel-ligència de les noies en los temps actuals" (90), Antonieta's imposition of an image on Pere Joan is no less fanciful than Florentina's inventions.

Antonieta's fortunes in the matter of her wedding are curiously linked to Florentina's romantic imaginings. Florentina longs for the 
exalted social position enjoyed by the heroines of her novels. She threatens to cancel her engagement to Josep if Antonieta goes through with her plans, on the grounds that she herself is making enough of a sacrifice in wedding a factory owner without becoming the sister-inlaw of a mere weaver. For his own part, Josep is ill-disposed to have his sister marry an humble textile worker and refuses to pay her dowry if she marries Pere Joan. In the novel's discourse of class, the characters who attempt to hide all evidence of the effort through which their families improved their economic and social position are represented as frivolous or misguided. In order to construct her vision of the textile industry, Monserdà must establish that a life encompassed and regulated by hard work is the formula for prosperity and success, as opposed to success achieved through manipulation of labor and finance. However, class ascendancy cannot be a reward for hard work in every case. Although Monserdà shows no sympathy for those whose prosperous appearance is unrelated to productive work, she also censures any public agitation for the betterment of labor conditions. As we will see later in the novel, a benevolent, paternalistic treatment of workers is not to be regulated by government but granted as part of a natural order.

As things turn out, Josep secretly finds it convenient to have a pretext for denying Antonieta her money, as Florentina's appetites for new furnishings, clothing and objets d'art have left him short of ready cash. Antonieta has little interest in buying new things for her wedding and is not disappointed with the loss of her dowry on that account. Nevertheless, she is concerned with her economic status and the material property that she will bring to her marriage. Monserdà represents Antonieta's break from Josep in order to establish the fact that her heroine is being taken to wife by the weaver solely for "ses qualitats morals" (I3I). However, as soon as the wedding has taken place, Antonieta is able to regain her economic standing in the marriage. Once the new couple has taken leave of their guests and are alone in their house for the first time, Antonieta leads her husband, not to the bedroom, but to a small workroom at the back of the house. She suggests that they forgo further wedding celebration, and use the time to set up a loom and begin weaving on their own account. On hearing her proposal that they work together side by side at the looms, for the first time Pere Joan looks at his wife with love, without seeing the image of his former fiancée, Roseta. The erotics of a wedding night are displaced by the economics of the birth of a family business.

Monserdà's representation of the married couple nearly always focuses on them as an economic unit. Antonieta carefully regulates the household expenditures; she prides herself on being able to stretch 
every resource beyond the usual limits. In spite of such care, the young business suffers its first setback when a client defaults on a payment, preventing the couple from purchasing new things for the child they are expecting. Antonieta is bitterly disappointed but not on her own account, as she explains to Pere Joan:

Ja saps que per mi mai m'ha fet il-lusió los luxos ni les vanitats, però pel nostre menut sí que la tinc, $\mathrm{j} i$ ben grossa!...aquest joc [de vesuari de batejar], ja $t^{\prime}$ ho he dit, des de que el vaig veure i em digueren lo preu, no he pogut pensar en altra cosa. I tant és així, que ja saps tu que jo, quan surto de casa, no sé passar pel davant de la capella de l'Ajuda que no hi entri, encara que sols sia a resar una salve a la Mare de Déu per a demanar-li que ens dongui salut i feina; doncs l'altre dia, tan capficada estava pensant en si els diners nos hi abastarien, que no vaig poguer menos que dir-li: " iVerge santíssima, salut i feina.,.i que li puguem comprar aquell vestidet al nen!",... (165)

While any desire to purchase things for herself would only signify vanity, Antonieta's desires to buy things for her child demonstrate her qualities as a mother and the skill with which she has nursed the family business until it can sustain expenditures on luxuries. Earlier in the novel, Antonieta sees Pere Joan and believes that her desire for him is ratified by a sign from God. On seeing a desired object in a shop window, some women might display their longing by symptoms of fevered agitation (Galdós' Rosalia Bringas comes to mind). Antonieta, however, resorts to fervent prayer. Just as Florentina expresses desire in terms of romance novels, Antonieta expresses her sexual and consumer desires in terms of the system of faith and religion in which she has been brought up.

It may be remembered that in her preface to the novel, Monserdà states that she is providing a record of a way of living and working that has disappeared forever. In part, the conflicts in the text seem to derive from the personal qualities of Antonieta and Florentina, from the differences in how their reading material has formed their expectations of men and of marriage. In the second half of the novel, however, Monserdà focuses on the conflict between old and new models of production and business and the impact this conflict has on domestic life. The ways in which the two cousins govern their husbands and manage household economy are shown to have parallels in the public world of work. The differences between the two women correspond to differences between two economic systems, one based on production of goods, the other based on speculation.

Never one to digress from her didactic intent, after marrying off both Antonieta and Florentina, Monserdà skips ahead fourteen years. During this time, Antonieta and her husband have become factory 
owners. Monserdà assures her readers that such an accomplishment was much more meaningful in 1875 than in 1904. She asserts that by the turn of the century, capitalists who had no previous connection with or knowledge of a craft could simply buy a factory and depend on machines, engineers and managers to keep things running smoothly. By contrast, in the time frame of the novel, a worker needed knowledge of his craft as well as intelligence and skill. If he had these things, then "fácilment passava de treballador a amo" (202). The transition from worker to owner was certainly not as easy as Monserdà describes, but she wishes to emphasize a causality in which result is a consequence of effort, a relationship between production and success that she seems to feel is missing in modern work.

According to Monserda, in 1875 industry was able to flourish in nearly ideal conditions. The Grau family has been able to turn a tidy profit "sense l'horrorosa amenaça de les bombes ni les pertorbacions de les vagues decretades més endavant pels autoritaris decrets de la Internacional" (203). The labor unrest of the late 1860's and early 1870 's, including the workers' burning of machines in several centers of textile manufacture is ignored in Monserdà's text in favor of a rewriting of industrial development in accordance with a model for the growth of a family. ${ }^{2}$ Antonieta has been active as the administrator and accountant of the business; she has strategized every stage of the couple's ascent from hand looms to machines, from piece-work to shops to, finally, the purchase of factories and real estate. Since Pere Joan is most interested in matters having to do with the actual manufacture of goods, Antonieta takes charge of management and lavishes a mother's care on the business until it has grown to strength and prosperity. Antonieta also cares for the workers as if they are her children, teaching them habits of hard work and frugality and supporting and tending to the sick whenever necessary. Antonieta's real child is invisible in the text, leaving her free to minister to the needs of her factory. No labor agitation is able to gain a foothold in any of the Grau factories because any malcontent is promptly reminded of how Antonieta has treated them as family in their time of misfortune.

Antonieta's mothering of the workers and business is an extension of the formula of the domestic angel. In her usual incarnation, the domestic angel makes the home a haven from the economic world. Monserdà's project, however, is to graft feminine nature onto the world of industry in order to present industry as stable, ordered and protective of workers' interests. Later on, however, Antonieta's incorporation of the business world into her

2. For further reading on labor unrest see Vives, 273-79. 
sphere does not come without its tensions. Having become an important person on various commercial boards and committees, Pere Joan has become too conscious of his public image to allow his wife to continue working. Antonieta does not wish open conflict with her husband, but she finds herself restless and unfulfilled by a narrow domestic role. In spite of the fact that her home is now luxuriously furnished, Antonieta has no interest in the homemaking activities of other bourgeois women. She feels herself to be like " a planta parásita entre els velluts i tapisseries que la voltaven" (206).

In Ladies of the Leisure Class, Bonnie G.Smith chronicles the radical changes that women's lives underwent once industrialization accomplished divisions of labor. Documenting her assertions with personal letters and memoirs, Smith claims that in the early nineteenth century, women worked side by side with men in production and management of business. Before the factory system, there was no clear boundary between work and home (34-36). This was especially true in the textile industry; Antonieta's insistence on commemorating her honeymoon by setting up a loom in the home is Monserdà's nostalgic evocation of marriage cemented by common labor and business concerns. However, with the "separation of residential and industrial areas," women are relegated to activities that are strictly domestic in nature (Smith 47). As the novel progresses, we see the pains that the transition to industrialization bring to Antonieta's domestic situation.

In order to gain relief from her boredom and isolation, Antonieta resorts to sneaking around on her husband, as it were, creeping down to the shop in order to look over the inventory and accounts:

...s'escorria com una ombra per l'escala de caragol que des del primer pis comunicava amb los baixos, i, una volta allí, amb los ulls brillants, animat lo rostre, alegre el cor per semblar-li que retornava a l'äpoca del seu antic regnat en aquells llocs.... (207)

The excitement with which Antonieta descends to the workshops and offices is almost like that of a woman going to meet a lover. After poring over the books, Antonieta delights in the sensual pleasure of the feel of the various fabrics until she hears her husband's footsteps approaching from down the street, then she hurries upstairs once more. Yet Antonieta's outlet is make-believe, she is only looking over the work another person has done as a substitute for active gratification.

On the surface, Antonieta may seem to have a completely pragmatic and realistic outlook, one that has "eliminat tots els elements de fantasia i passió" (Tayadella 540). But her life does have 
elements of fantasy and desire; sexual desires, desires for consumer goods, desires to sometimes be in different situations or circumstances. These desires are expressed within an ethic of work and faith which Monserdà favors over the imaginative, "Bovariste" ethic of Florentina. Yet, to say that Monserdà invests one framework for articulating desire and experience with moral authority is not exactly the same thing as saying that the privileged framework is real, although Monserdà herself seems to be unaware of the distinction.

Since her marriage fourteen years before, Florentina's condition has deteriorated considerably. While still beautiful, she seems to be suffering from some kind of nervous disorder, a consequence, we later learn, of her passion for fiction. ${ }^{3}$ Her skin has a yellow cast, and she eats very irregularly. She is too distracted to pay attention to the needs of her family, consequently her children also have an unhealthy color. There is even the dangerous possibility that the mother's malady will be contagious to the next generation. Florentina has become so careless of the children's education that her twelve year old daughter has several times been caught by her father in the act of reading novels.

Over the years Florentina has insisted on foreign travel and on the purchase of both a town and a country house. She buys clothing, jewelry and furs at her whim. Yet Florentina is no longer interested in consumerism as a public spectacle; as she protests to Josep during one holiday stroll, "tinc ganes de ser a casa. Ja saps que no sóc dona de passeig... Me sembla que fa poble, això..." (I83). Florentina is so taken over by her interior life, she prefers not to go outside at all anymore but to stay indoors reading novels during every spare moment. Her hobby has reached the point of an addiction. Her reading has created such a keen dissatisfaction with the world around her that she is overwhelmed by "un febrós desig d'aconteixements i sensacions parescuts als que llegia" (I96). Florentina, in her idleness, is a victim of the division of male and female labor described by Smith. Antonieta resists the social changes that take her out of the workplace, but Florentina retreats even desper into the world of novels and fantasy.

Florentina has very little idea of the value of money, and indeed the characters in the novels she reads tend to show a disdain for monetary considerations. The one financial issue in which she cares to interfere is that of her husband's profession. Certainly no heroine of a romance was ever the wife of a textile manufacturer, so Florentina uses everything in her feminine arsenal of persuasion to get Josep to sell his factory and become a speculator. In this way, she reasons, he

3. For further reading on the relations between addiction, reading, imagination and active life in women's consciousness see Campbell, 175-77 and Ronell, 100-03. 
will not associate with workers, and his means of getting money will be as invisible as possible. Josep's new profession does not involve real production, for he trades on values that are only speculative. His daily "work" now seems just as firmly grounded in unreality as Florentina's daily activity of reading novels.

Unfortunately, Pep is bitterly unhappy to have given up the family factory. In renouncing productive work, he has had to sacrifice his adolescent ideal of domesticity: that of his parents working side by side in the business. ${ }^{4}$ Yet although Josep regrets the absence of elements of domestic industry in his life, he has become accustomed to Florentina's influence in other aspects of domesticity. On a visit to his sister's home, Pep finds the atmosphere of the house so cold and uniform that it reminds him of a tomb. He admits to himself that, despite her eccentricities, Florentina has devised a more attractive home, with a more pleasing array of goods than her sister-in-law. However, the charming home that Josep appreciates so much becomes a crushing burden once he bankrupts himself through speculation. Antonia must save her brother from his entanglement in a parasitical economy and save herself from what she characterizes as an unproductive existence at home by devising a plan that will restore them both to active management of a factory and unite the two halves of the family once again.

According to some formulations of the domestic angel, Antonieta may be seen as remiss in her duty to use the material resources at her disposal in order to create a pleasant and comfortable living space. Yet in order for industry to have the human face that Monserdà envisions, a domestic woman must be at the helm. Moreover, in her nostalgia for a bygone era in which husbands and wives shared their work, Monserdà elects to discount the issue of homemaking in order to emphasize Antonieta's qualities as a producer, not a consumer of goods. Material comforts become the concern only of persons like Florentina, who, under pressure of the new domestic ideology, are willing to waste energy and imagination on such matters. However, Florentina's imagination turns out to be an economic liability; through her fantastic expectations she constructs a marriage and a domestic economy that have no relation to her husband as he actually is or to money as it is actually available. Of course, the framework of

4. In her introduction to La fabricanta, Teresa Pàmies mentions that Josep Corominas is reminiscent of Gil Foix in Narcís Oller's La febre d'or. See "Pròleg a tres veus," 16. While both men are speculators, I feel that the resemblance ends there. Josep is unhappy as a speculator, while Gilet gets along swimmingly. Moreover, Monserda represents speculation as a parasitical enterprise carried on at the ultimate expense of workers, while Oller feels that the stock market is essential in order to mobilize the huge amounts of capital required by emergent heavy industries. 
values through which Antonieta views the world may be no less of a construct. From Monserdà's perspective, however, the advantage of Antonieta's piety, industry, and thrift is that they are not only morally conservative but materially conservationist as well.

KATHLEEN DAVIS TULANE UNIVERSITY

\section{WORKS CiTED}

CAmpbell, Colin. The Romantic Ethic and the Spirit of Modern Consumerism. Oxford: Basil Blackwell, 1987.

MONSERDA DE MACIȦ, Dolors. "A nostras lectoras." Modas y Labors (February 15, 1880) 1 .

- "Carta oberta a la redacció del setmanari Or y Grana." Or y Grana (October 6, 1906) 3-4.

- La fabricanta: Novel.la de costums barcelonines (1860-1875) Ed. Teresa Pàmies. Barcelona: Edicions de l' Eixample, 1992.

RONELl, Avital. Crack Wars: Literature Addiction Mania. Lincoln, NE: U of Nebraska P, 1992.

SmITH, Bonnie G. Ladies of the Leisure Class: The Bourgeoises of Northern France in the Nineteenth Century. Princeton, NJ: Princeton U P, 198I.

TAYADElla i Oller, Antònia. "La novel-la realista" Historia de la literatua catalana. Eds. Marti de Riquer and Joaquim Molas. Vol. VII. Barcelona: Editorial Ariel, 1986.

VICENS VIVES, Jaime. Catalunya en el Siglo XIX. Madrid: Ediciones Rialp, 196. 